\title{
Nutrition - Sensitive Agriculture: A Paradigm for Achieving Nutrition Sovereignty
}

\author{
B.R. Sneha ${ }^{1}$, S.K. Kammar ${ }^{1}$, M.B. Shanabhoga ${ }^{2 *}$ and Shivani Dechamma ${ }^{2}$ \\ ${ }^{1}$ Department of Agricultural Extension Education University of Agricultural Sciences, \\ Raichur, Karnataka, India \\ ${ }^{2}$ Department of Agricultural Extension, University of Agricultural Sciences, Bangalore, \\ Karnataka, India \\ *Corresponding author
}

\begin{abstract}
A B S T R A C T
\section{Key wo r d s}

Nutrition, Sensitive agriculture,

Paradigm,

Sovereignty

\section{Article Info}

Accepted:

24 August 2018

Available Online:

10 September 2018

India is home to one-third of the world's undernourished children. According to the third National Family Health Survey (NFHS-3), one-third of Indian children are born with low birth weight, 45 percent of children below three years of age are stunted, 23 percent are wasted, and 40 percent are underweight. Nutrition Sensitive Agriculture is the Interventions or programmes that address the underlying determinants of fetal and child nutrition and development - food security; adequate care giving resources at the maternal, household and community levels; and access to health services and a safe and hygienic environment - and incorporate specific nutrition goals and actions. Nutrition-sensitive programmes can serve as delivery platforms for nutrition-specific interventions, potentially increasing their scale, coverage, and effectiveness. A huge disconnect exist between agriculture and nutrition. There is an urgent need to narrow this gap. Agriculture based interventions are absolutely needed to achieve nutrition sovereignty. Nutrition-sensitive agriculture is one of such initiatives to achieve the stated goal of livelihood security by integrating both the sectors.
\end{abstract}

\section{Introduction}

India is home to one-third of the world's undernourished children. According to the third National Family Health Survey (NFHS3), one-third of Indian children are born with low birth weight, 45 percent of children below three years of age are stunted, 23 percent are wasted, and 40 percent are underweight. Under nutrition remains one of the most challenging and pressing public health problems in India, despite some decline in the numbers of around 40 per cent of the world's stunted children and nearly 50 per cent of all wasted children in India (Haddad et al., 2015). Poor nutritional status, particularly in early life, can have lifelong consequences for physical and psychological well-being and can also impair long-term employment opportunities (Black et al., 2013). Around the world 795 million people are under nourished, Asia and pacific accounts for almost $62 \%$ of this section. In Indian scenario 194.6 million people are malnourished according to annual 
report by FAO (Food and Agriculture Organization) of United Nations. It is not only children who are affected by under nutrition: one-third of women and adolescent girls in India are chronically energy-deficient (Meshram et al., 2015).

One of the potential ways of tackling persistent under nutrition in India is strengthening the role of agriculture (Gillespie et al., 2012). A number of studies have explored the pathways by which agriculture may improve nutrition in India (Gillespie et al., 2012; Welch, 2001; Mahendra, 2012; Kataki and Babu, 2002; Haddad, 2000; Gillespie and Kadiyala, 2012; Bhagowalia et al., 2012). Agriculture can help to improve diets (qualitatively and quantitatively), generate income and employment, empower women and improve female health (Kadiyala et al., 2014).

Agriculture connect with the nutrition in several ways, but there exist a huge disconnect exist between agriculture and nutrition. There is an urgent need to narrow this gap. FAO is trying to bring some nutrition interventions in different sectors with an aim of 'multi-sectoral approaches' at global level in collaboration with many of the institutions. Nutritionsensitive agriculture is one of them. Nutritionsensitive agriculture (NSA) is an approach that seeks to maximize agriculture's contribution to nutrition. This strategy stresses the multiple benefits derived from enjoying a variety of foods, recognizing the nutritional value of food for good nutrition, health, productivity and the social significance of the food and agricultural sector supporting rural livelihoods. Finally, it involves linking agriculture to sectors that address other causes of malnutrition, namely education, health and social protection (Bibi Giyose, 2014). Despite the benefits of a more nutrition-sensitive agriculture, its full potential is still underused in India (Kadiyala et al., 2011).

\section{What is meant by "Nutrition Sensitive Agriculture?"}

An official definition of nutrition sensitivity is now available via the 2013 Lancet Series on Maternal and Child Nutrition, as follows:

Interventions or programmes that address the underlying determinants of fetal and child nutrition and development - food security; adequate care giving resources at the maternal, household and community levels; and access to health services and a safe and hygienic environment - and incorporate specific nutrition goals and actions. Nutrition-sensitive programmes can serve as delivery platforms for nutrition-specific interventions, potentially increasing their scale, coverage, and effectiveness (Ruel and Alderman, 2013).

There have been calls to place a higher priority on "unleashing" (IFPRI, 2012), "leveraging" (Pell et al., 2011), "reshaping" (Fan and Pandya-Lorch, 2012), or "realizing" (IFAD 2011) the opportunities offered by agriculture to enhance nutrition and health (Webb and Kennedy, 2012; Webb, 2013).

In addition to nutrition sensitivity, the terminology now includes "nutrition enhancing," which is endorsed by the Food and Agriculture Organization (FAO) as a description of: Agriculture and food systems that effectively and explicitly incorporate nutrition objectives, concerns and considerations, improve diets and raise levels of food and nutrition security.

Nutrition enhancing actions may include: "Making more nutritious food more accessible to everyone or to specific targeted groups, supporting small holders and boosting women's incomes, ensuring clean water and sanitation, education and employment, health care, support for resilience and empowering women in a deliberate attempt to explicitly 
improve diets and raise levels of nutrition" (FAO, 2010).

Nutrition-sensitive agriculture is a food-based approach to agricultural development that puts nutritionally rich foods, dietary diversity, and food fortification at the heart of overcoming malnutrition and micronutrient deficiencies. This approach stresses the multiple benefits derived from enjoying a variety of foods, recognizing the nutritional value of food for good nutrition, and the importance and social significance of the food and agricultural sector for supporting rural livelihoods. The overall objective of nutrition-sensitive agriculture is to make the global food system better equipped to produce good nutritional outcomes (Second International Conference on Nutrition, FAO, 2014)

The NSA approach could be developed in quite distinct perspectives depending on existing conceptual matrices, institutional designs and political projects in each national context. (Renato Sergio et al., 2015)

The global governance mechanisms for agriculture are also repositioning nutrition as central to the evolution of agriculture and food systems: nutrition is being mainstreamed across the work of the FAO, and nutrition challenges and solutions are discussed in the Committee for World Food Security (CFS), as well as the Committees for Agriculture (COAg), Fisheries (COFI), and Forestry (COFO). This political momentum is both carried by, and giving rise to, a growing body of work on crop production and nutrition, livestock and nutrition, nutrition-sensitive value chains, biodiversity and nutrition, natural resources and nutrition and integrating nutrition in agriculture extension (Charlotte Dufour, 2016).

Nutrition sensitive agriculture aims to maximise the impact of nutrition outcomes for the poor, while minimising the unintended negative nutrition consequences of agricultural interventions and policies on the poor, especially women and young children. It is agriculture with a nutrition lens, and should not detract from the sector's own goals. Agriculture projects may also affect water quality, disease occurrence, food safety and women's time use (which, in turn, affects child care practices) - each of which are important for nutrition (The World Bank, Rapid Social Response, DFID, Government of Japan, 2013).

\section{Research gaps in the agriculture-nutrition nexus}

Despite agriculture's potential to affect nutrition in several ways, the current knowledge about linkages between the two is extraordinarily weak. Studies that analyze malnutrition typically progress along three lines of inquiry: (1) consumption of calories, (2) micro- and macronutrient intakes, and (3) anthropometric measures. Studies on agriculture have tended to focus on agricultural productivity, incomes, and price trends. The paucity of unit-level data that combine information on both nutrition and agriculture is itself a form of "empirical disconnect" between agriculture and malnutrition (Stuart Gillespie and Suneetha Kadiyala, 2011)

Research that considers the full pathway of change from agricultural inputs, practices, value chains, food environment to nutrition outcomes.

The indirect effect of changes in agriculture on nutrition, through income and economic growth and associated changes in health and investments in health and education services.

The effects of agricultural policy on nutrition as mediated through the value chain. 
Governance, policy processes and political economy as it relates to the development of agriculture-for nutrition policies and programmes, the ability to implement them (and scale up) and for them to achieve their stated goals once implemented.

The way research on agriculture and nutrition is conducted, such as the development of methodologies and appropriate metrics.

Consumers as a broader target group, notably rural workers and non-rural populations.

The rural and urban poor at risk from nutrition-related non-communicable diseases

Cost-effectiveness (Hawkes et al., 2012, in Meeker and Haddad, 2013)

\section{Pathways between Agriculture and Nutrition}

The pioneering United Nations Children's Fund (UNICEF) conceptual framework for nutrition (UNICEF 1990) has proved extremely useful in showing the relevance of the food, health, and care triad of preconditions that underpin nutritional wellbeing. Seven key (Staurt et al., 2011) pathways between agriculture and nutrition, which are as follows:

Agriculture as a source of food, the most direct pathway by which household agricultural production translates into consumption (via crops cultivated by the household)

Agriculture as a source of income, either through wages earned by agricultural workers or through the marketed sales of food produced

The link between agricultural policy and food prices, involving a range of supply-and- demand factors that affect the prices of various marketed food and nonfood crops, which, in turn, affect the incomes of net sellers and the ability to ensure household food security (including diet quality) of net buyers

Income derived from agriculture and how it is actually spent, especially the degree to which nonfood expenditures are allocated to nutrition-relevant activities (for example, expenditures for health, education, and social welfare)

Women's socioeconomic status and their ability to influence household decision making and intra household allocations of food, health, and care

Women's ability to manage the care, feeding, and health of young children

Women's own nutritional status, when their work-related energy expenditure exceeds their intakes, their dietary diversity is compromised, or their agricultural practices are hazardous to their health (which, in turn, may affect their nutritional status) (Staurt et al., 2011).

\section{Main focusing areas of nutrition sensitive agriculture}

Making food more available and accessible. Increasing agricultural production makes more food available and affordable, which improves both the health and the economic status of the community. Sustained income growth in turn has a sizeable effect on reducing malnutrition.

Making food more diverse and production more sustainable. Increasing diversity in food production and promoting sustainable production practices like conservation agriculture, water management and integrated pest management can improve nutrition levels without depleting natural resources. Family 
farming, home gardens and homestead food production projects can make a wider variety of crops available at the local level. Making food itself more nutritious. Fortification can prevent micronutrient deficiencies by enhancing micronutrient content in foods through processing, plant breeding and improved soil fertility. In addition to changes in the agriculture sector, governments can promote nutrition-sensitive agriculture by incorporating nutrition sensitive concepts into relevant farm policies and programs (Second International Conference on Nutrition 2014).

\section{Need of multi sectoral approach in nutrition sensitive agriculture}

Agricultural and rural development projects usually assume they have an inherent impact on nutrition because they contribute to general agricultural growth and increases in rural incomes.

However, to tackle malnutrition effectively in the short and medium term, agriculture should take advantage of the many other ways that it can more directly affect nutrition.

Those in the agricultural sector must also learn to partner more effectively with other sectors, especially health, education, and water and sanitation, in order to address the multi sectoral causes of malnutrition more completely (James and Kennedy, 2015).

Nutrition-specific interventions are key to accelerating progress. However, it is also critical that other sectors-like agriculture, education, and social welfare- develop nutrition-sensitive interventions. A truly multi-sectoral approach will achieve optimal nutrition outcomes through greater coverage, while also helping other programmes achieve more powerful results and demonstrate their own potential for impact (UNICEF and
European Union, Maternal and Young Child Nutrition Security Initiative in Asia (MYCNSIA).

\section{Agriculture}

Programmes that boost agricultural production, keep prices low, and increase incomes are critical but they can still leave children vulnerable to the life-long effects of poor nutrition. Research shows that nutritionsensitive programmes can enhance access to diverse diets in poor populations, foster women's empowerment, and support livelihoods (Alderman and Ruel, 2013).

\section{Education}

When education programmes invest in nutrition, it improves academic achievement with the potential for substantial gains in the cost, efficiency, and effectiveness of programmes (Bundy et al., 2009).

\section{Social welfare}

Efforts to lift poor families out of poverty are undermined unless good nutrition is part of the investment. When social protection programmes become nutrition-sensitive, they can improve diet quantity, quality, and diversity; decrease vulnerability to food insecurity; decrease child mortality; and help children reach their full potential (Gilligan et al., 2008; Freeland and Cherrier, 2012).

\section{Public health}

Public health and nutrition are interdependent. Diarrhoea and pneumonia are the biggest killers of children in the Asia and Pacific region deaths that are largely preventable through breastfeeding and adequate nutrition, hand washing with soap, safe drinking water and basic sanitation, and vaccination. 
Table.1 FAO promotes nutrition-sensitive agriculture through a variety of partnerships and capacity development initiatives, some of the examples are

\begin{tabular}{|c|c|c|c|}
\hline Institute & Country & Programmes & Activities \\
\hline \multirow[t]{2}{*}{$\begin{array}{l}\text { World Food } \\
\text { Programme (WFP) }\end{array}$} & 62 countries & $\begin{array}{l}\text { Home grown school } \\
\text { meals programme } \\
(2015)\end{array}$ & Linking school meals to local agriculture \\
\hline & 20 countries & $\begin{array}{l}\text { P4P } \\
\text { Purchase for } \\
\text { Progress(2008) }\end{array}$ & $\begin{array}{l}\text { Purchase for Progress (P4P) is } \\
\text { connecting smallholder farmers to } \\
\text { markets, giving them an opportunity to } \\
\text { grow their businesses and improve their } \\
\text { lives and those of their entire } \\
\text { communities and increase food security } \\
\text { and nutrition. }\end{array}$ \\
\hline $\begin{array}{l}\text { Food and } \\
\text { Agriculture } \\
\text { Organization } \\
\text { (FAO) }\end{array}$ & $\begin{array}{l}\text { Cambodia } \\
\text { Malawi }\end{array}$ & $\begin{array}{l}\text { IMCF } \\
\text { Improve food } \\
\text { security and } \\
\text { Complementary } \\
\text { Feeding }\end{array}$ & $\begin{array}{l}\text { Evaluates the impact of combining } \\
\text { behavior change communication with } \\
\text { promoting production, consumption of } \\
\text { diverse, locally available, nutrition- } \\
\text { dense and affordable foods. }\end{array}$ \\
\hline $\begin{array}{l}\text { Institute of } \\
\text { Development } \\
\text { Studies (IDS) } \\
\text { and } \\
\text { M S Swaminathan } \\
\text { Research } \\
\text { Foundation } \\
\text { (MSSRF) }\end{array}$ & $\begin{array}{l}\text { India } \\
\text { Bangladesh } \\
\text { Afghanistan } \\
\text { Pakistan }\end{array}$ & $\begin{array}{l}\text { LANSA } \\
\text { Leveraging } \\
\text { Agriculture for } \\
\text { Nutrition in South } \\
\text { Asia }\end{array}$ & $\begin{array}{l}\text { The majority of LANSA's research } \\
\text { addresses women empowerment, } \\
\text { overarching question: How can South } \\
\text { Asian agriculture and related food } \\
\text { policies and interventions be designed } \\
\text { and implemented to increase their } \\
\text { impacts on nutrition. }\end{array}$ \\
\hline \multirow[t]{2}{*}{$\begin{array}{l}\text { International Food } \\
\text { Policy Research } \\
\text { Institute (IFPRI) }\end{array}$} & $\begin{array}{l}\text { Bangladesh } \\
\text { India } \\
\text { Ethiopia } \\
\text { Kenya }\end{array}$ & $\begin{array}{l}\text { Transform Nutrition } \\
\text { (2011) }\end{array}$ & $\begin{array}{l}\text { Is designed to reflect the current } \\
\text { consensus that nutrition specific } \\
\text { interventions, nutrition sensitive } \\
\text { activities and supports sustained and } \\
\text { significant progress in reducing under } \\
\text { nutrition. }\end{array}$ \\
\hline & Zambia & $\begin{array}{l}\text { RAIN } \\
\text { Realigning } \\
\text { Agriculture to } \\
\text { Improve Nutrition } \\
\text { (2011) }\end{array}$ & $\begin{array}{l}\text { It support for improved production of } \\
\text { high quality foods, delivery of social } \\
\text { behavior change communication around } \\
\text { nutrition and health practices }\end{array}$ \\
\hline $\begin{array}{l}\text { Helen Keller } \\
\text { International } \\
\text { (HKI) } \\
\end{array}$ & $\begin{array}{l}\text { Asia and } \\
\text { Africa }\end{array}$ & $\begin{array}{l}\text { Homestead Food } \\
\text { Production } \\
\text { Programmes }\end{array}$ & $\begin{array}{l}\text { In order to improve maternal and child } \\
\text { health and nutritional outcome }\end{array}$ \\
\hline $\begin{array}{l}\text { United States } \\
\text { Agency for } \\
\text { International } \\
\text { Development } \\
\text { (USAID) }\end{array}$ & 20 countries & $\begin{array}{l}\text { Feed The Future } \\
\text { (FTF) }\end{array}$ & $\begin{array}{l}\text { It is working actively to better integrate } \\
\text { nutrition into agriculture projects. } \\
\text { Increasing agriculture productivity, } \\
\text { Expanded market and trade and increase } \\
\text { investment in agriculture. }\end{array}$ \\
\hline
\end{tabular}

Source: (FAO, WFP, IDS, IFPRI, Aberman and powell, 2011, Berhane et al., 2011, Hensen et al., 2013) 
Table.2 Agriculture and food system interventions for better nutrition

\begin{tabular}{|c|c|c|}
\hline Food system elements & Nutrition opportunities & Policy tools \\
\hline Production & $\begin{array}{l}\text { Sustainable intensification of production } \\
\text { - } \quad \text { Nutrition-promoting farm systems, } \\
\text { agronomic practices, crops, livestock, fish } \\
\text { and wild food } \\
\text { - } \quad \text { Micronutrient fertilizers } \\
\text { - } \text { Biofortified crops } \\
\text { - } \text { Integrated farming systems, including } \\
\text { - } \text { fisheries and forestry } \\
\text { - } \quad \text { Stability for food and nutrition security } \\
\text { - } \quad \text { Nutrition education } \\
\text { - } \quad \text { School and home gardens } \\
\text { - } \quad \text { Nutrient-preserving on-farm storage }\end{array}$ & $\begin{array}{l}\text { - Food and agricultural } \\
\text { policies to promote } \\
\text { availability, affordability, } \\
\text { diversity and quality } \\
\text { - Nutrition-oriented } \\
\text { agricultural research on } \\
\text { crops, livestock and } \\
\text { production systems } \\
\text { - Promotion of school and } \\
\text { home gardens }\end{array}$ \\
\hline $\begin{array}{l}\text { Post-harvest supply } \\
\text { chain "from the } \\
\text { farm gate to the } \\
\text { retailer": } \\
\text { marketing, storage, } \\
\text { trade, processing and } \\
\text { retailing }\end{array}$ & $\begin{array}{l}\text { - Nutrient-preserving and nutrient-enhancing } \\
\text { processing, packaging, transport and storage } \\
\text { - Reduced waste and increased technical and } \\
\text { economic efficiency } \\
\text { - Food fortification } \\
\text { - Reformulation for better nutrition (e.g. } \\
\text { elimination of trans fats) } \\
\text { - Food safety }\end{array}$ & $\begin{array}{l}\text { Regulation and taxation } \\
\text { to promote efficiency, } \\
\text { safety, quality and } \\
\text { diversity } \\
\text { Research and promotion } \\
\text { of innovation in product } \\
\text { formulation, processing } \\
\text { and transport }\end{array}$ \\
\hline $\begin{array}{l}\text { Consumers } \\
\text { (advertising, } \\
\text { labelling, education, } \\
\text { safety nets) }\end{array}$ & $\begin{array}{l}\text { - Nutrition information and health claims } \\
\text { - } \text { Product labeling } \\
\text { - } \text { Consumer education } \\
\text { - Social protection for food and nutrition } \\
\text { - } \text { security } \\
\text { - } \text { General food assistance programmes and } \\
\text { - Tabsidies } \\
\text { children, elderly, etc.) }\end{array}$ & $\begin{array}{ll}\text { - } & \text { Food assistance } \\
\text { Programmes } \\
\text { - } & \text { Food price incentives } \\
\text { - } & \text { Nutrition regulations } \\
\text { behavion education, } \\
\text { communication and } \\
\text { information campaigns }\end{array}$ \\
\hline
\end{tabular}

Source: (FAO. 2013. The State of Food and Agriculture: Food Systems for Better Nutrition. Rome)

14 Delivery of micronutrient supplements through antenatal care services can also reduce maternal death and low birth weight significantly (Bhutta et al., 2013).

\section{Nutrition education}

Nutrition education is need of the hour to make people informed choices about the foods they grow, purchase and eat. Indeed, the success of food-based strategies to eliminate nutritional deficiencies will rest on the willingness of individuals to change their dietary habits.

However, information and education must go beyond issues concerning individuals. They should also include social, economic and political factors that influence food patterns and choice by population groups. 


\section{Role of agriculture extension workers in promoting NSA}

Agricultural extension officers can provide guidance on development regarding what crops can be grown in the area and which are the most preferred and profitable.

They can also help local farmers select the varieties and landraces of local seeds best suited to the environment and they can advise the community on seed propagation and distribution.

They can able to build a nutrition education communication network through at farmers' clubs and credit organizations.

They can also devise technical messages to encourage farmers to produce and to market a wider variety of crops, and develop and promote in collaboration with local farmers more extensive mixed cropping system, organic farming and home gardens to maximize use of the available land. (FAO, 2010)

\section{Major constraints in implementing NSA}

Lack of collaboration and coordination with other sectors

Less importance given to the nutrition dense food. In many of the countries not embedded nutrition objectives in agriculture policies.

Inadequate technical knowledge about nutritional aspects to field level extension workers.

Very low women's access to extension services and lees number of women extension workers.

More importance is given to food securities than nutrition security. (Hawkes et al., 2012;
Meeker and Haddad, 2013)

A huge disconnect exist between agriculture and nutrition. There is an urgent need to narrow this gap. Agriculture based interventions are absolutely needed to achieve nutrition sovereignty. Nutrition-sensitive agriculture is one of such initiatives to achieve the stated goal of livelihood security by integrating both the sectors. Hence, nutrition objectives are to be embedded in agricultural policies. It is high time for extension system needs to gear up to play a major role in motivating and educating farmers to go for innovative strategies that integrate agriculture and nutrition.

\section{References}

Aberman, N.L. 2011. Ethiopia Stakeholder Mapping Report. Addis Ababa: Transform Nutrition and IFPRI.

Berhane, G., Dereje, M., Hoddinott, J., Koru, B., Nisrane, F., Tadesse, F., Taffesse, A.S., Worku, I., Yohannes, Y. 2011, Agricultural Growth Program (AGP) of Ethiopia: Baseline Report 2011. Ethiopia Strategy Support Program II. Addis Ababa: IFPRI.

FAO. 2014. Proceedings of the Preparatory Technical Meeting for the Joint FAO/WHO Second International Conference on Nutrition (ICN2). Rome: FAO.

Mesham, A. R. and Chatterje, M., 1999, The crises of malnutrition in India, World Bank, Washington DC.1, 13-24.

Nadia, B., Stefano, P., Balaravi, S. and Nirmala, Y., 2010, Minor millets in India: a neglected crop goes mainstream. https://www.bioversity international.org. 314- 324.

Ruel, M.T., Alderman, H. and the Maternal and Child Nutrition Study Group. 2013. Nutrition-sensitive interventions and programmes: how can they help to 
accelerate progress in improving maternal and child nutrition? The Lancet - 6 June 2013. DOI: 10.1016/S0140-6736(13)60843-0.

Stuart, G., Jody, H. and Kadiyala, 2011, The agriculture - nutrition disconnect in India what do we know? IFPRI discussion paper01187: 1-16.
WFP. 2013. Update on the Nutrition Policy. Excerpt from Annual Session of the Executive Board. Rome: FAO World Bank. 2007. From Agriculture to Nutrition: Pathways, Synergies and Outcomes. Washington DC: World Bank.

www.fao.orgicn2

\section{How to cite this article:}

Sneha, B.R., S.K. Kammar, M.B. Shanabhoga and Shivani Dechamma. 2018. Nutrition Sensitive Agriculture: A Paradigm for Achieving Nutrition Sovereignty. Int.J.Curr.Microbiol.App.Sci. 7(09): 3455-3463. doi: https://doi.org/10.20546/ijcmas.2018.709.428 